\title{
STEROWANIE ZESTAWEM ARTYLERYJSKO-RAKIETOWYM Z WYKORZYSTANIEM ZMODYFIKOWANEGO REGULATORA LINIOWO-KWADRATOWEGO
}

\begin{abstract}
W niniejszej pracy przedstawiono opracowanie układu sterowania zdalnie sterowanym zestawem artyleryjsko-rakietowym z wykorzystaniem regulatora LQR (liniowo-kwadratowego). Model zestawu wyprowadzono, opierając się na produkowanym w Polsce zestawie ZU 23-2MR. W pracy omówiono linearyzację modelu matematycznego zestawu za pomocą Jakobianów, przedstawiono strukturę i budowę układu regulacji oraz zaproponowano sposób niwelacji uchybu sterowania w stanie ustalonym bez wykorzystania dodatkowych członów całkujących, występujących w układzie regulacji. Badaniom poddano także wpływ oddziaływania zakłóceń pochodzących od strzelającej armaty na dokładność sterowania w trakcie śledzenia manewrującego celu. Przeanalizowano również wpływ niedokładności identyfikacji parametrów obiektu sterowania na pracę układu. Symulacje numeryczne przeprowadzono z wykorzystaniem środowiska Scilab, a najistotniejsze wyniki zostały przedstawione w postaci graficznej.
\end{abstract}

Słowa kluczowe: sterowanie, LQR, regulator liniowo-kwadratowy, linearyzacja, obiekt nieliniowy

\section{Wprowadzenie}

Na współczesnym polu walki istnieje potrzeba ustawicznego zwiększania zdolności bojowych, w tym prędkości działania, zasięgu wykrywania celów, możliwości identyfikacji celów i skuteczności prowadzenia ognia przez zestawy artyleryjsko-rakietowe krótkiego zasięgu. Dużym wyzwaniem jest możliwość skutecznego prowadzenia ognia przez tego typu zestawy w warunkach oddziaływania zakłóceń nie tylko ze strony strzelającej armaty, lecz także ze strony poruszającej się platformy, na której jest posadowiona armata i samonaprowadzające

\footnotetext{
1 Autor do korespondencji: Piotr Szmidt, Politechnika Świętokrzyska, al. Tysiąclecia Państwa Polskiego 7, 25-314 Kielce, e-mail: pszmidt@tu.kielce.pl

2 Zbigniew Koruba, Politechnika Świętokrzyska, e-mail: ksmzko@tu.kielce.pl

${ }^{3}$ Daniel Gapiński, Politechnika Świętokrzyska, e-mail: dgapinski@tu.kielce.pl
} 
pociski rakietowe. Ponadto, zestaw stanowi układ ze zmienną masą, gdyż w krótkim czasie można wystrzelić od kilku do kilkudziesięciu, a nawet kilkuset pocisków - ma się zatem do czynienia z układem silnie nieliniowym ze zmiennymi parametrami (niestacjonarnym). Należy nadmienić, że obecnie w Polsce trwają prace nad wymienionymi zagadnieniami i dotyczą armaty kalibru $35 \mathrm{~mm}$ $[1,2]$.

W pracy tej zajęto się doborem sterowania dla modelu zestawu opartego na zestawie artyleryjsko-rakietowym ZU 23-2MR. Na rysunku 1. przedstawiono model CAD wymienionego zestawu. Jest to jeden z najpopularniejszych zestawów wykorzystywanych i produkowanych w Polsce. Został wyposażony w podwójnie sprzężoną armatę kalibru $23 \mathrm{~mm}$ oraz dwa pociski rakietowe GROM o zasięgu $5,5 \mathrm{~km}$. Zestaw jest przeznaczony do zwalczania lekkoopancerzonych samolotów, śmigłowców lub obiektów nawodnych z maksymalną donośnością armaty $3 \mathrm{~km}$ w poziomie i szybkostrzelnością praktyczną wynoszącą 400 strzałów na minutę [3].

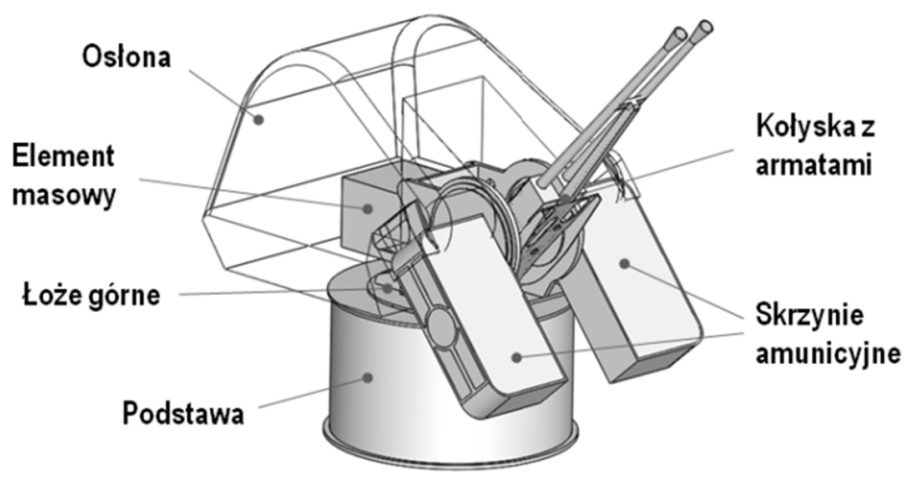

Rys. 1. Model zestawu wykonany w programie CAD

Fig. 1. Model of the system designed in CAD software

\section{Model matematyczny zestawu}

Model matematyczny dynamiki ruchu zestawu został wyprowadzony na podstawie równania Lagrange'a II rodzaju, w wyniku czego otrzymano równania momentów uogólnionych. Na potrzeby zaprojektowania regulatora LQR dynamikę układu należy jednak przedstawić w postaci równań stanu. Wektor stanu $\mathbf{x}$ zapisano następująco:

$$
\mathbf{x}=\left[x_{1}, x_{2}, x_{3}, x_{4}\right]^{\mathrm{T}}
$$

gdzie: $x_{1}$ - położenie kątowe w azymucie, $x_{2}$ - prędkość kątowa w azymucie, $x_{3}$ - położenie kątowe w elewacji, $x_{4}$ - prędkość kątowa w elewacji. 
Następnie równania dynamiki zapisano jako układ czterech nieliniowych równań różniczkowych pierwszego rzędu o postaci:

$$
\dot{x}_{i}=f_{i}+g_{i}, \quad i=1,2,3,4
$$

gdzie: $f_{i}$ - część (funkcja) zależna od zmiennych stanu (dynamika własna układu), $g_{i}$ - część zależna od sterowania i zakłóceń (oddziaływania z zewnątrz).

Jako zewnętrzne oddziaływania dynamiczne przyjęto momenty napędowe $M_{1}$ i $M_{2}$, powstające na wyjściu reduktorów i działające na układ ruchu odpowiednio w azymucie i elewacji oraz momenty $Z_{1}$ i $Z_{2}$, tj. chwilowe zakłócenia związane $\mathrm{z}$ oddawaniem strzałów. Pochodne wektora stanu stanowiące model dynamiki układu są dane równaniami:

$$
\begin{aligned}
& \dot{x}_{1}=\overbrace{x_{2}}^{f_{1}}+\stackrel{\stackrel{\leftrightarrow}{0}_{0}}{g_{1}} \\
& \dot{x}_{2}=\overbrace{\frac{-\left(3 a x_{3}^{2}+2 b x_{3}+c\right) x_{2} x_{4}-t_{11} x_{2}^{3}-t_{12} x_{2}}{I_{1}+p n+q+a x_{3}^{3}+b x_{3}^{2}+c x_{3}+d}+}^{f_{2}}+ \\
& +\overbrace{\frac{M_{1}+Z_{1}}{g_{2}}}^{I_{1}+p n+q+a x_{3}^{3}+b x_{3}^{2}+c x_{3}+d} \\
& \dot{x}_{3}=\overbrace{x_{4}}^{f_{3}}+\stackrel{g_{3}}{0} \\
& \dot{x}_{4}=\frac{\overbrace{0,5\left(3 a x_{3}^{2}+2 b x_{3}+c\right) x_{2}^{2}-t_{21} x_{4}^{3}-t_{22} x_{4}-I_{2}\left[\sin \left(x_{1}\right) \ddot{\alpha}_{x}+\cos \left(x_{1}\right) \ddot{\alpha}_{y}\right]}^{f_{4}}}{I_{2}}+ \\
& +\frac{\overbrace{-m g r \cos \left(x_{3}+\gamma+\alpha_{x} \sin x_{1}+\alpha_{y} \cos x_{1}\right)}^{f_{4} c . d .}}{I_{2}}+\overbrace{\frac{M_{2}+Z_{2}}{I_{2}}}^{g_{4}}
\end{aligned}
$$

gdzie: $I_{1}$ - stały masowy moment bezwładności wieżyczki, $p n+q-$ zmienny masowy moment bezwładności wieżyczki zależny od liczby naboi w skrzyniach $n$, $I_{2}$ - stały masowy moment bezwładności kołyski z armatami względem osi obrotu w elewacji, $a x_{3}^{3}+b x_{3}^{2}+c x_{3}+d$ - zmienny masowy moment bezwładności kołyski z armatami względem osi obrotu w azymucie, zależny od kąta elewacji, $m$ masa kołyski z armatami, $g$ - przyspieszenie grawitacyjne, $r$ - odległość środka ciężkości kołyski z armatami względem osi obrotu w elewacji, $\gamma$ - kątowe przemieszczenie środka ciężkości kołyski z armatami względem osi luf, $t_{11}, t_{12}, t_{21}, t_{22}$ 
- współczynniki nieliniowych aproksymacji funkcji tarcia w przegubach, $\alpha_{x}, \alpha_{y}-$ przemieszczenia kątowe podstawy zestawu [4].

Obliczenie macierzy wzmocnień $\mathbf{K}$ regulatora liniowo-kwadratowego wymaga znajomości liniowego modelu układu w postaci $\dot{\mathbf{x}}=\mathbf{A x}+\mathbf{B u}$, gdzie sterowanie $\mathbf{u}=\left[M_{1}, M_{2}\right]^{\mathrm{T}}$. W celu wyznaczenia macierzy stanu $\mathbf{A}$ oraz macierzy sterowania $\mathbf{B}$ skorzystano z Jakobianów. Poszczególne elementy macierzy A są dane według zależności (7). Linearyzacja następuje w danym punkcie pracy $\mathbf{x}^{*}$ dla aktualnego stanu układu w chwili linearyzacji.

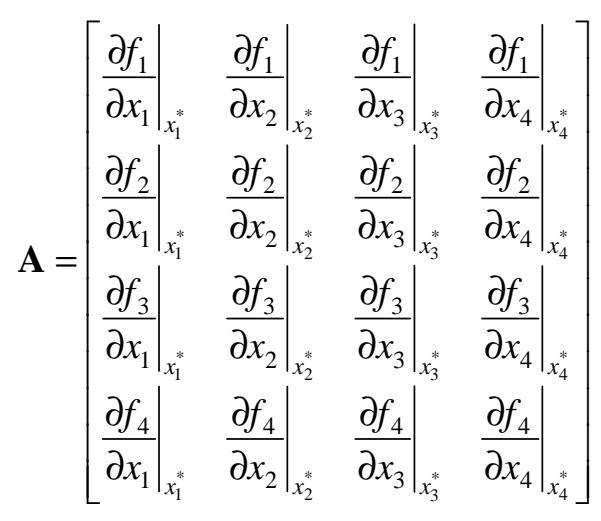

Po obliczeniu symbolicznym pochodnych cząstkowych uzyskano rozwiązania kolejnych elementów macierzy A, które przedstawiają równania:

$$
\begin{aligned}
& \left.\frac{\partial f_{1}}{\partial x_{1}}\right|_{x_{1}^{*}}=0,\left.\frac{\partial f_{1}}{\partial x_{2}}\right|_{x_{2}^{*}}=1,\left.\frac{\partial f_{1}}{\partial x_{3}}\right|_{x_{3}^{*}}=0,\left.\frac{\partial f_{1}}{\partial x_{2}}\right|_{x_{2}^{*}}=0 \\
& \left.\frac{\partial f_{2}}{\partial x_{1}}\right|_{x_{1}^{*}}=0,\left.\frac{\partial f_{2}}{\partial x_{2}}\right|_{x_{2}^{*}}=\frac{3 t_{11}\left(x_{2}^{*}\right)^{2}+t_{11}-\mid 3 a\left(x_{3}^{*}\right)^{2}+2 b x_{3}^{*}+c x_{4}^{*}}{I_{1}+a\left(x_{3}^{*}\right)^{3}+b\left(x_{3}^{*}\right)^{2}+c x_{3}^{*}+d+n p+q} \\
& \left.\frac{\partial f_{2}}{\partial x_{3}}\right|_{x_{3}^{*}}=-\frac{2 x_{2}^{*} x_{4}^{*}\left(3 a x_{3}^{*}+b\right)\left[I_{1}+a\left(x_{3}^{*}\right)^{3}+b\left(x_{3}^{*}\right)^{2}+c x_{3}^{*}+d+n p+q\right]}{\left[I_{1}+a\left(x_{3}^{*}\right)^{3}+b\left(x_{3}^{*}\right)^{2}+c x_{3}^{*}+d+n p+q\right]^{2}}+ \\
& +\frac{\left[3 a\left(x_{3}^{*}\right)^{2}+2 b x_{3}^{*}+c\right]\left[-x_{2}^{*} x_{4}^{*}\left[3 a\left(x_{3}^{*}\right)^{2}+2 b x_{3}^{*}+c\right]+t_{11}\left(x_{2}^{*}\right)^{3}+t_{12}\left(x_{2}^{*}\right)\right]}{\left[I_{1}+a\left(x_{3}^{*}\right)^{3}+b\left(x_{3}^{*}\right)^{2}+c x_{3}^{*}+d+n p+q\right]^{2}} \\
& \left.\frac{\partial f_{2}}{\partial x_{4}}\right|_{x_{4}^{*}}=-\frac{\left[3 a\left(x_{3}^{*}\right)^{2}+2 b x_{3}^{*}+c\right] x_{2}^{*}}{I_{1}+a\left(x_{3}^{*}\right)^{3}+b\left(x_{3}^{*}\right)^{2}+c x_{3}^{*}+d+n p+q}
\end{aligned}
$$




$$
\begin{aligned}
& \left.\frac{\partial f_{3}}{\partial x_{1}}\right|_{x_{1}^{*}}=0,\left.\frac{\partial f_{3}}{\partial x_{2}}\right|_{x_{2}^{*}}=0,\left.\frac{\partial f_{3}}{\partial x_{3}}\right|_{x_{3}^{*}}=0,\left.\frac{\partial f_{3}}{\partial x_{4}}\right|_{x_{4}^{*}}=1 \\
& \left.\frac{\partial f_{4}}{\partial x_{1}}\right|_{x_{1}^{*}}=\frac{\operatorname{mgr}\left(\tau_{y} \sin x_{1}^{*}-\tau_{x} \cos x_{1}^{*}\right) \sin \left(x_{3}^{*}+\tau_{x} \sin x_{1}^{*}+\tau_{y} \cos x_{1}^{*}+\gamma\right)}{I_{2}}- \\
& +\frac{\left.I_{2} \ddot{\tau}_{x} \cos x_{1}^{*}+\ddot{\tau}_{y} \sin x_{1}^{*}\right)}{I_{2}} \\
& \left.\frac{\partial f_{4}}{\partial x_{2}}\right|_{x_{2}^{*}}=\frac{\left[3 a\left(x_{3}^{*}\right)^{2}+2 b x_{3}^{*}+c\right] x_{2}^{*}}{I_{2}} \\
& \left.\frac{\partial f_{4}}{\partial x_{3}}\right|_{x_{3}^{*}}=\frac{\left[3 a x_{3}^{*}+b\right]\left(x_{2}^{*}\right)^{2}+m g r \sin \left(x_{3}^{*}+\tau_{x} \sin x_{1}^{*}+\tau_{y} \cos x_{1}^{*}+\gamma\right)}{I_{2}} \\
& \left.\frac{\partial f_{4}}{\partial x_{4}}\right|_{x_{4}^{*}}=0
\end{aligned}
$$

Zlinearyzowana macierz sterowania $\mathbf{B}$ ma natomiast postać daną wzorem:

$$
\mathbf{B}=\left[\begin{array}{ll}
\left.\frac{\partial g_{1}}{\partial u_{1}}\right|_{x^{*}} & \left.\frac{\partial g_{1}}{\partial u_{2}}\right|_{x^{*}} \\
\left.\frac{\partial g_{2}}{\partial u_{1}}\right|_{x^{*}} & \left.\frac{\partial g_{2}}{\partial u_{2}}\right|_{x^{*}} \\
\left.\frac{\partial g_{3}}{\partial u_{1}}\right|_{x^{*}} & \left.\frac{\partial g_{3}}{\partial u_{2}}\right|_{x^{*}} \\
\left.\frac{\partial g_{4}}{\partial u_{1}}\right|_{x^{*}} & \left.\frac{\partial g_{4}}{\partial u_{2}}\right|_{x^{*}}
\end{array}\right]
$$

Po obliczeniu pochodnych cząstkowych uzyskano następujące rozwiązania symboliczne:

$$
\begin{aligned}
& \left.\frac{\partial g_{1}}{\partial u_{1}}\right|_{x^{*}}=0,\left.\quad \frac{\partial g_{1}}{\partial u_{2}}\right|_{x^{*}}=0 \\
& \left.\frac{\partial g_{2}}{\partial u_{1}}\right|_{x^{*}}=\frac{1}{I_{1}+p n+q+a\left(x_{3}^{*}\right)^{3}+b\left(x_{3}^{*}\right)^{2}+c x_{3}^{*}+d},\left.\quad \frac{\partial g_{2}}{\partial u_{2}}\right|_{x^{*}}=0
\end{aligned}
$$




$$
\begin{aligned}
& \left.\frac{\partial g_{3}}{\partial u_{1}}\right|_{x^{*}}=0,\left.\quad \frac{\partial g_{3}}{\partial u_{2}}\right|_{x^{*}}=0 \\
& \left.\frac{\partial g_{4}}{\partial u_{1}}\right|_{x^{*}}=0,\left.\quad \frac{\partial g_{4}}{\partial u_{2}}\right|_{x^{*}}=\frac{1}{I_{2}}
\end{aligned}
$$

\section{Układ sterowania}

Zaproponowany schemat struktury układu sterowania przedstawiono na rys. 2. Układ sterowania opiera się na zmodyfikowanym regulatorze LQR, w którym macierze A i B stanowią liniowy model obiektu sterowania w danym punkcie jego pracy. Macierze są wyznaczane z taką samą częstotliwością, z jaką pracuje cyfrowy regulator. W założonym układzie regulacji jako elementy wykonawcze przyjęto serwonapędy z silnikiem bezszczotkowym typu SBL 4-0530 o maksymalnym momencie obrotowym $\pm 21 \mathrm{Nm}$ [5]. Serwonapęd razem z reduktorem zamodelowano jako człon inercyjny I rzędu, ze stałą czasową $\mathrm{T}=0,02 \mathrm{~s}$ [4]. Oznacza to, że na zestaw artyleryjsko-rakietowy nie może działać moment napędowy dokładnie taki, jak z wyjścia regulatora (tj. nie może się zmieniać skokowo). $Z$ lewej strony schematu widnieje blok sygnału zadanego (np. wyjście z optoelektronicznej głowicy skanująco-śledzącej) oraz blok korektora uchybu ustalonego, który zostanie szerzej omówiony w dalszej części pracy.

Założono, że wektor stanu układu jest w pełni znany. Składowe wektora stanu, czyli położenie i prędkości kątowe w azymucie i elewacji mogą być fizycznie mierzone za pomocą czujników, np. enkoderów położenia kątowego oraz indukcyjnych czy optycznych sensorów prędkości kątowej. Dzięki znajomości pełnego wektora stanu i innych wielkości, takich jak pozostała liczba naboi w skrzyniach, nieliniowy model dynamiki zestawu można poddać linearyzacji w aktualnym punkcie jego pracy. Model liniowy z kolei może posłużyć do wyznaczenia sterowania optymalnego dla liniowo-kwadratowego wskaźnika jakości danego ogólnie wzorem [6]:

$$
J=\int_{0}^{\infty} \mathbf{x}^{\mathbf{T}} \mathbf{Q} \mathbf{x}+\mathbf{u}^{\mathbf{T}} \mathbf{R} \mathbf{u} d t
$$

gdzie: $\mathbf{Q}$ - macierz wag zmiennych stanu, $\mathbf{R}$ - macierz wag (kosztu) sterowania. 


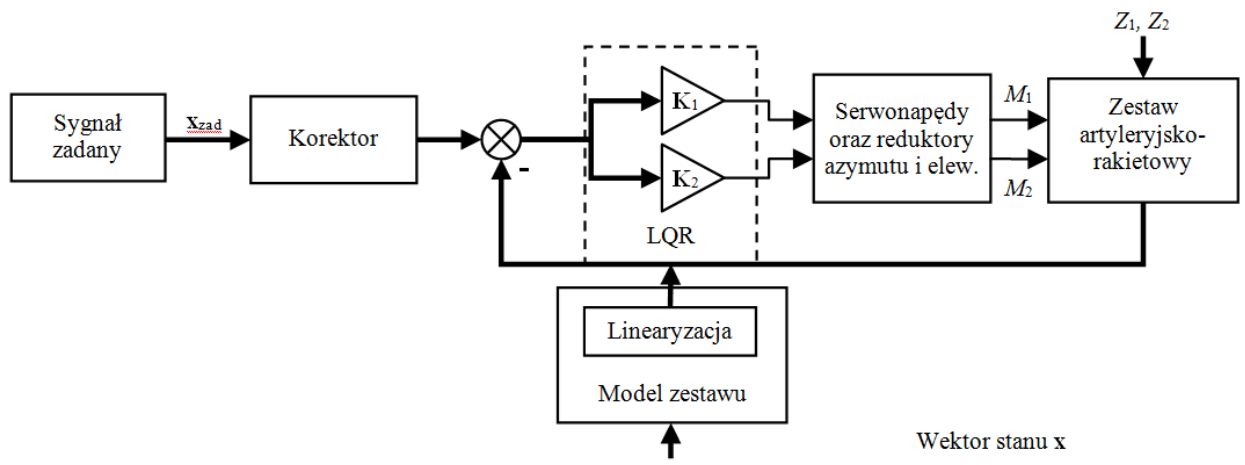

Rys. 2. Struktura układu sterowania ze zmodyfikowanym regulatorem LQR

Fig. 2. Control system structure with the modified LQR controller

Dla rozpatrywanych dalej symulacji dobrano iteracyjnie macierz $\mathbf{Q}$ oraz macierz $\mathbf{R}$, przy czym wartości początkowe przyjęto według pracy [7]:

$$
\begin{aligned}
& \mathbf{Q}=\left[\begin{array}{cccc}
500 & 0 & 0 & 0 \\
0 & 100 & 0 & 0 \\
0 & 0 & 1000 & 0 \\
0 & 0 & 0 & 4
\end{array}\right] \\
& \mathbf{R}=\left[\begin{array}{ccc}
0,000001 & 0 \\
0 & 0,000001
\end{array}\right]
\end{aligned}
$$

Dla regulatora $L Q R$ prawo sterowania w podstawowej formie jest wyrażane wzorem (14). Do wyznaczenia macierzy wzmocnień $\mathbf{K}$ posłużono się gotową funkcją lqr zawartą w pakiecie Scilab [6], wewnątrz której jest rozwiązywane równanie różniczkowe Riccatiego:

$$
\mathbf{u}=-\mathbf{K}\left(\mathbf{x}_{\mathrm{zad}}-\mathbf{x}\right)
$$

gdzie $\mathbf{x}_{\text {zad }}$ - zadany wektor stanu układu.

W efekcie użycia funkcji lqr uzyskuje się macierz wzmocnień obu regulatorów, tj. $\mathbf{K}^{(4 \times 2)}=\left[\mathbf{K}_{1}^{(4 \times 1)} \mathbf{K}_{2}^{(4 \times 1)}\right]$.

W związku z niewystarczającym rzędem astatyzmu układu elewacji następuje wyraźny uchyb ustalony dla regulacji stałowartościowej. Aby zminimalizować ten uchyb, wprowadzono pewną funkcję korygującą $k\left(x_{3 z a d}\right)$. Postać funkcji na podstawie doświadczeń symulacyjnych została aproksymowana funkcją wielomianową 3. rzędu: 


$$
k\left(x_{3 z a d}\right)=0,0195 x_{3}^{3}-0,2799 x_{3}^{2}+0,2222 x_{3}+0,478
$$

Postać funkcji (15) wynika $\mathrm{z}$ tego, że zbadano uchyb ustalony dla zadanych, stałych położeń kątowych z zakresu od -10 do $90^{\circ}$. Na podstawie zebranych punktów pomiarowych dopasowano krzywą wielomianową (rys. 3.). Ostatecznie, jako sygnał zadany do układu regulacji jest wprowadzane skorygowane położenie zadane w elewacji $\hat{x}_{3 z a d}$, dane wyrażeniem:

$$
\hat{x}_{3 z a d}=x_{3 z a d}+k\left(x_{3 z a d}\right)
$$

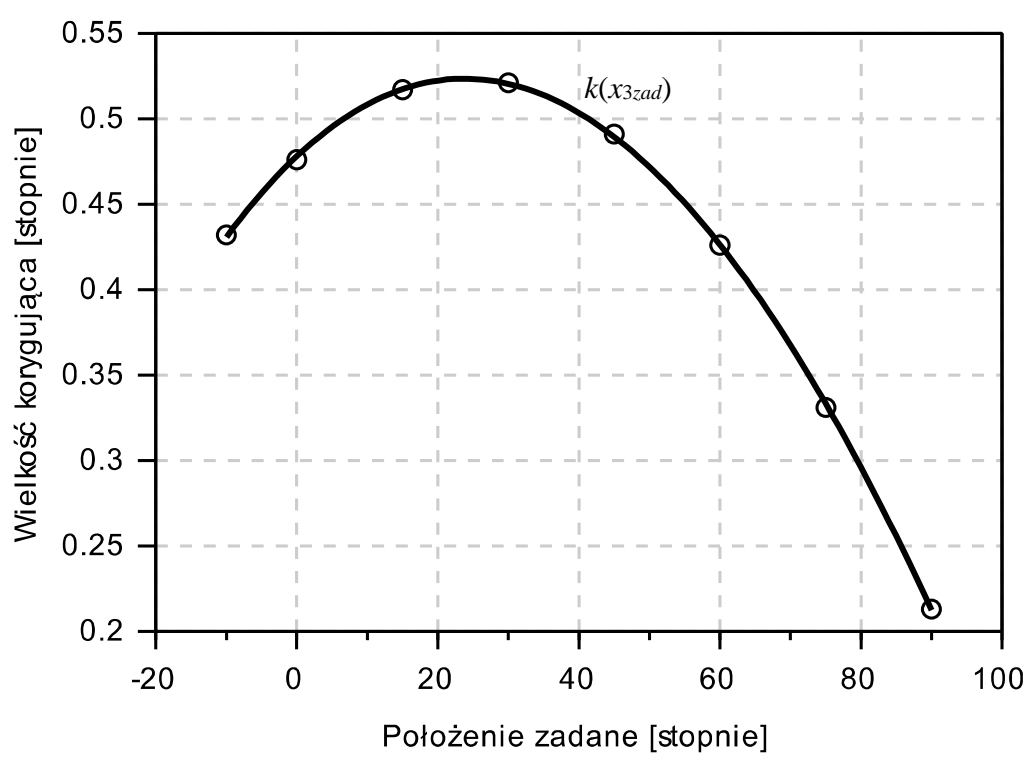

Rys. 3. Przebieg funkcji korygującej $k\left(x_{3 z a d}\right)$ na tle punktów pomiaru uchybu

Fig. 3. Correction function $k\left(x_{3 z a d}\right)$ and measured error points

Rezultat działania funkcji korygującej przedstawiają rys. 4. i 5. W chwili $t=2 \mathrm{~s}$ następuje seria wystrzałów modelowana jako trójkątne impulsy momentu obrotowego o czasie trwania $0,0019 \mathrm{~s}$ i działającego na układ elewacji (w jednym kierunku) i azymutu (naprzemiennie). Na rysunkach 4 a i 5a pokazano przebieg wypracowanego kąta w elewacji bez korekcji, natomiast na rys. $4 \mathrm{~b}$ i $5 \mathrm{~b}$ - przebieg wypracowanego kąta $\mathrm{z}$ włączoną korekcją w układzie. Funkcja korekcji w stosunku do członu całkującego ma tę zaletę, że nie powoduje pogorszenia innych parametrów regulacji, takich jak zwiększenie czasu regulacji czy zwiększenie oscylacyjności. Badania symulacyjne wykazały, że po wprowadzeniu członu całkującego zamiast funkcji korekcji wymienione wcześniej parametry ulegały wyraźnemu pogorszeniu dla nastawy członu całkującego, która powodowałaby 
likwidację uchybu ustalonego. Dla regulacji LQR położenia w układzie azymutu uchyb ustalony jest znikomy.

a)

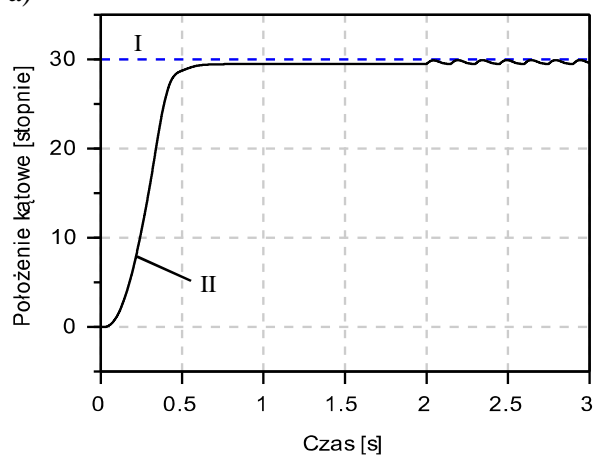

b)

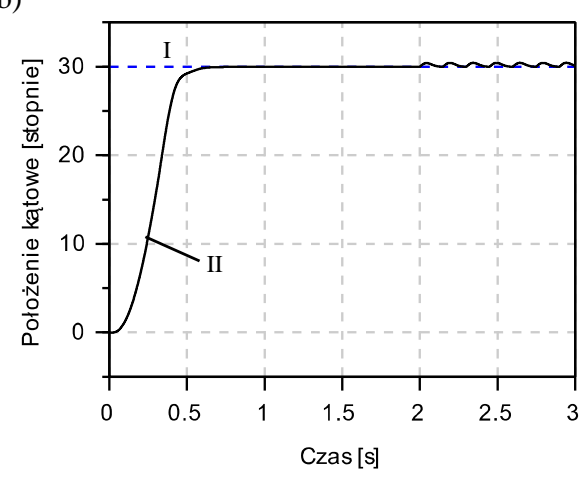

Rys. 4. Sterowanie w układzie elewacji: a) bez korekcji, b) z korekcją uchybu ustalonego. Przebieg zadany (I), przebieg realizowany (II)

Fig. 4. Control in the elevation system: a) without correction, b) with the steady error correction. Desired (I) and performed (II) trajectories

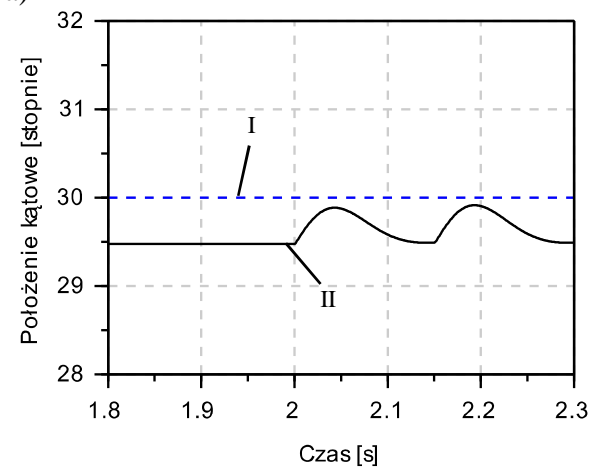

b)

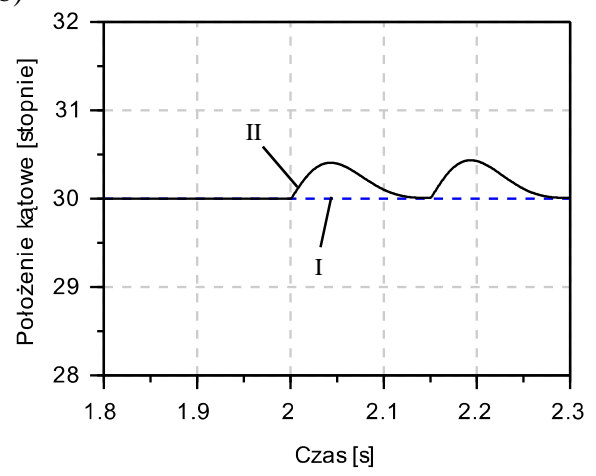

Rys. 5. Powiększony fragment z rys. 3: a) bez korekcji, b) z korekcją uchybu ustalonego; widoczne zakłócenia od strzałów. Przebieg zadany (I), przebieg realizowany (II)

Fig. 5. Enlarged part of fig. 3: a) without correction, b) with the steady error correction; disturbances from firing can be seen. Desired (I) and performed (II) trajectories

\section{Przykład symulacyjny śledzenia celu}

W prezentowanej symulacji zbadano nie tylko możliwość śledzenia manewrującego celu, ale i odporność na oddziaływanie zakłóceń od strzałów w trakcie śledzenia oraz odporność regulacji na niedokładność identyfikacji parametrów 
modelu obiektu sterowania. Różnica pomiędzy obiektem sterowania (zestawem) a linearyzowanym modelem, na podstawie którego jest wyznaczane sterowanie, polegała na celowym zwiększeniu parametrów obiektu sterowania: o $30 \%$ momentu bezwładności $I_{1}$ oraz o $20 \%$ masy kołyski z armatami $m$. Założono jednocześnie, że podstawa zestawu jest nieruchoma, tj. $\alpha_{\mathrm{x}}(t)=0 \mathrm{i} \alpha_{\mathrm{y}}(t)=0$.

a)

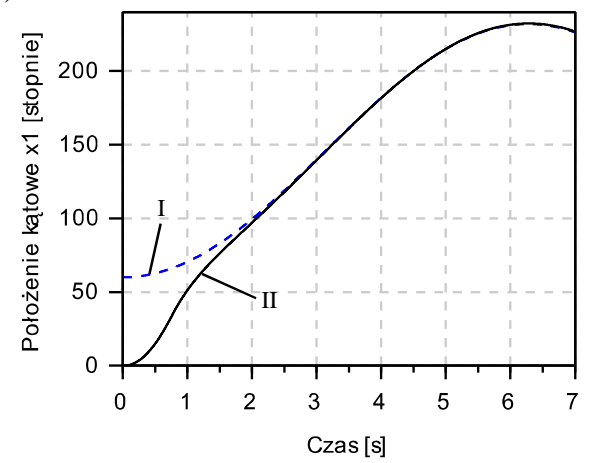

b)

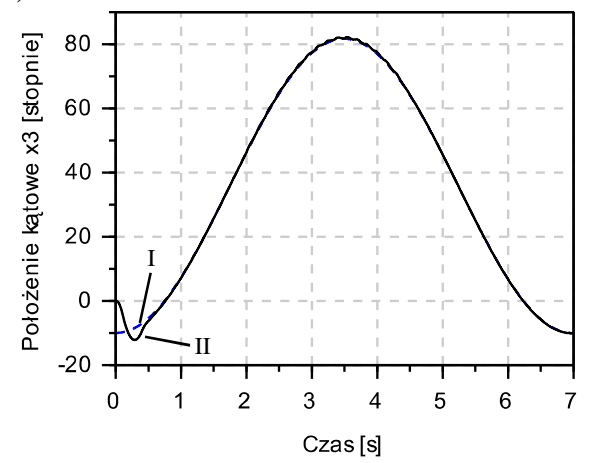

Rys. 6. Przebiegi zadane (I) i realizowane (II) przez zestaw w układzie: a) azymutu, b) elewacji

Fig. 6. Desired (I) and performed (II) trajectories in: a) azimuth, b) elevation

Przykładową trajektorię śledzenia celu i realizowany ruch przedstawia rys. 6. Warunki początkowe obiektu sterowania są różne od zadanych, zatem w pierwszej fazie następuje nakierowanie zestawu na zadaną trajektorię, a następnie po czasie ok. 2 s oddawana jest seria 15 strzałów. Zakłócenia pochodzące od strzałów są szczególnie widoczne w przypadku układu elewacji, co przedstawiono na rys. 7b. Dla układu azymutu (rys. 7a) oddziaływanie zakłóceń od strzałów jest znacznie mniej widoczne, co wynika ze znacząco większej masy (bezwładności) wieżyczki w stosunku do kołyski.

Na rysunku 8. przedstawiono momenty sterujące wypracowane przez napędy w trakcie wykonywania prezentowanego ruchu. Wyraźnie widać chwile oddawania strzałów, gdzie następuje dynamiczna reakcja układu regulacji w celu kompensacji zakłóceń. Wytworzone momenty napędowe nie osiągają jednak swoich maksymalnych wartości (nie następuje nasycenie), ze względu na występującą w układzie napędowym bezwładność. 
a)

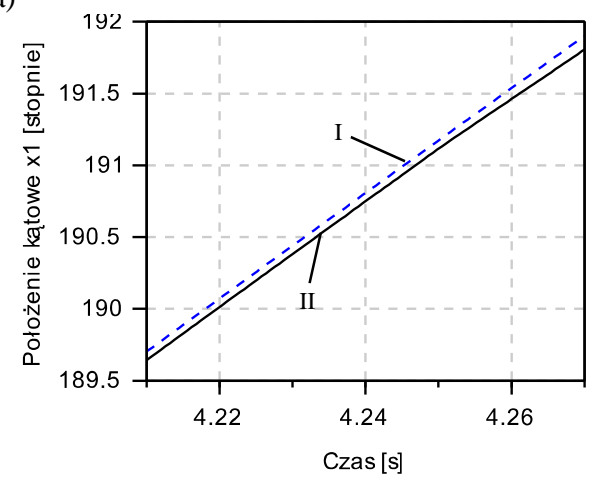

b)

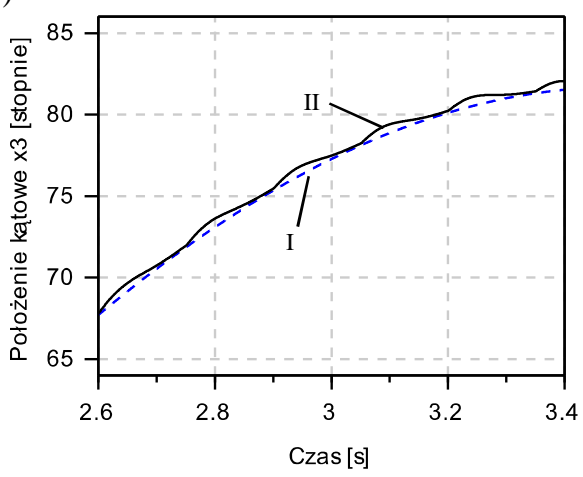

Rys. 7. Powiększenie fragmentów przebiegów zadanych (I) i realizowanych (II) z rys. 6.: a) w azymucie, b) w elewacji

Fig. 7. Enlargement of the desired (I) and performed (II) trajectories from Fig. 6.: a) azimuth, b) elevation

a)

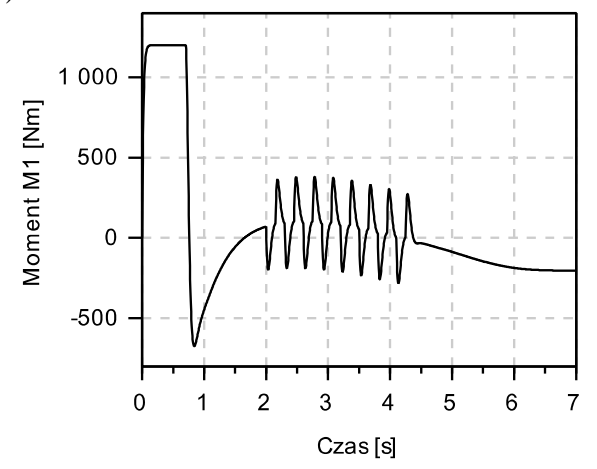

b)

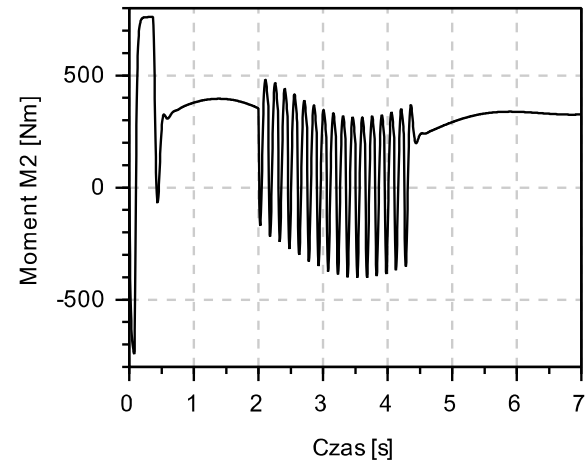

Rys. 8. Momenty napędowe układu: a) azymutu, b) elewacji

Fig. 8. Drive torques for: a) azimuth, b) elevation

\section{Wnioski}

W pracy przedstawiono sposób linearyzacji modelu matematycznego dynamiki zestawu artyleryjsko-rakietowego typu ZU 23-2MR. Liniowy model posłużył z kolei do implementacji regulatora LQR, czego efektem jest wyznaczenie macierzy wzmocnień, stanowiącej podstawę prawa sterowania dla omawianego typu regulacji. Następnie zaproponowano sposób kompensacji uchybu ustalonego, polegającej na wprowadzeniu nieliniowej funkcji korygującej sygnał zadany dla położenia w elewacji. Wykazano, że sposób ten poprawia dokładność 
pozycjonowania zestawu w zadanym położeniu oraz przy oddziaływaniu zakłóceń pochodzących od strzałów.

Należy nadmienić, że zbudowany układ regulacji działa bardzo poprawnie również w przypadku, gdy model nie jest tożsamy z obiektem sterowania. Wprowadzone celowo rozbieżności wartości parametrów modelu obiektu i obiektu sterowania nie spowodowały znaczącego pogorszenia jakości sterowania. W przypadku omawianego układu regulacji dokładność śledzenia trajektorii w przypadku zarówno azymutu, jak i elewacji wynosi ok. $0,1^{\circ}$. Zakłócenia od strzałów są poprawnie kompensowane - do chwili następnego strzału układ powraca do zadanego położenia ze wspomnianą dokładnością. Dalsze prace związane z układem sterowania opartym na zmodyfikowanym regulatorze LQR mogą poddawać analizie optymalizację wartości macierzy wag. Macierze te są bardzo istotne z punktu widzenia jakości sterowania i ich numeryczna optymalizacja mogłaby wpłynąć na poprawę tej jakości.

Kolejnym istotnym aspektem będzie optymalizacja użycia zasobów obliczeniowych w układzie regulacji. Wyliczanie Jakobianów w każdym kroku wymaga znaczącej mocy obliczeniowej, aby zachować rygor czasowy i zapewnić pracę układu w czasie rzeczywistym. Na testowanym komputerze (procesor Intel i3 4000M, 8 GB Ram) krytyczny krok całkowania wyniósł $d t=0,0006 \mathrm{~s}$. Dalsze zmniejszanie kroku powodowało, że czas obliczeń był dłuższy niż czas końcowy symulacji, co oznacza, że obliczeń nie dałoby się wykonać w czasie rzeczywistym. W przypadku układów ze zmianami tak dynamicznymi jak oddziaływania pochodzące od wystrzałów konieczne jest zapewnienie odpowiednio wysokiej częstotliwości pracy układów regulacji i napędu.

\section{Literatura}

[1] Dura M.: Armata 35 mm dla Kormorana, http://www.defence24.pl/292995,fbm-armata-35-mm-tryton-dla-kormorana (dostęp: 02.03.2018).

[2] Gacek J., Gwardecki J., Kobierski J., Leciejewski Z., Łuszczak S., Milewski S., Świętek T., Woźniak R., Wójcik Z.: Structure and innovative technologies in the new Polish $35 \mathrm{~mm}$ naval weapon system, 11th Int. Armament Conf. Scientific Aspects of Armament \& Safety Technology 2016, pp. 246-247.

[3] Zakłady Mechaniczne Tarnów, $23 \mathrm{~mm}$ przeciwlotniczy morski zestaw artyleryjsko-rakietowy ZU-23-2MR, http://www.zmt.tarnow.pl/wordpress (dostęp: 02.03.2018).

[4] Szmidt P.: A compensation for positioning of the remote control artillery-missile set in external disturbance conditions, Vibration, Control Stability Dynamical Systems, 23 (2017) 513-524.

[5] Motor Technology Ltd., SBL/K Motor Catalogue, http://docplayer.net/5976825-Sblk-motor-catalogue-2002.html (dostęp: 02.03.2018).

[6] Ashish T.: Modern control design with Matlab and Simulink, Wiley, New York 2002.

[7] Koruba Z:: The control of the artillery-rocket set in conditions of random interferences, Vibration, Control Stability Dynamical Systems, 23 (2017) 203-214.

[8] Scilab - dokumentacja, https://help.scilab.org/docs (dostęp: 15.02.2018). 


\title{
CONTROL OF MISSILE-ARTILLERY SYSTEM WITH MODIFIED LINEAR-QUADRATIC REGULATOR
}

\begin{abstract}
A bstract
This paper presents the development of a remote-controlled artillery-rocket control system using the LQR (linear-quadratic regulator). The system model was derived on the basis of the ZU 23-2MR set manufactured in Poland. The work discusses linearization of the mathematical model of the system with the help of Jacobians, presents the structure of the control system and proposes a method of minimizing the control error in the steady state, without the use of additional integrating elements occurring in the control system. The study also examined the impact of interference from a shooting cannon on the accuracy of control while tracking a maneuvering target. The influence of inaccurate identification of control object parameters on system operation was also analyzed. Numerical simulations were carried out using the Scilab environment, and the most important results were presented in the graphic form.
\end{abstract}

Keywords: control, LQR, linear-quadratic regulator, linearization, non-linear plant

DOI: $10.7862 / \mathrm{rm} .2018 .19$

Przestano do redakcji: 25.04 .2018

Przyjęto do druku: 26.05.2018 
